Relations industrielles

Industrial Relations

\title{
II - The necessity for structural reform
}

The Structure of Enterprise

\section{Marcel Clément}

Volume 3, numéro 6, février 1948

URI : https://id.erudit.org/iderudit/1023599ar

DOI : https://doi.org/10.7202/1023599ar

Aller au sommaire du numéro

Éditeur(s)

Département des relations industrielles de l’Université Laval

ISSN

0034-379X (imprimé)

1703-8138 (numérique)

Découvrir la revue

Citer cet article

Clément, M. (1948). II - The necessity for structural reform: The Structure of Enterprise. Relations industrielles / Industrial Relations, 3(6), 87-91.

https://doi.org/10.7202/1023599ar

Tous droits réservés @ C Département des relations industrielles de l’Université Laval, 1948
Ce document est protégé par la loi sur le droit d'auteur. L'utilisation des services d'Érudit (y compris la reproduction) est assujettie à sa politique d'utilisation que vous pouvez consulter en ligne.

https://apropos.erudit.org/fr/usagers/politique-dutilisation/ 


\section{II.-THE NECESSITY FOR STRUCTURAL REFORM}

\section{THE STRUCTURE OF ENTERPRISE}

\section{Marcel CLEMENT}

When the construction of a house is finished the beams and girders can no longer be distinguished. None-the-less, it is this framework, hidden by the outer casing, which gives to the building its form and foundation. The architect had made a plan for this framework. If he made an error the construction will show traces of it. If the error were serious it could happen that the house would collapse.

A similar principle can be discovered in living entities. As an organism developes the initial cells multiply and show differentiation. Certain of them become bone-making cells. They grew harder as they begin to form the skeleton. That skeleton, though not apparent, gives to the living body its shape and strength and, for each different species, has a form perfectly adapted to the functioning of the various organs. The skeleton collaborates in the conditioning of the organism in a spontaneous and quite unconscious fashion. The perfectioning of this same conditioning results from a finality or guiding principle which, in turn, is derived from the Author of all life. It is never a matter of hazard or the will of the living individual.

In the same way all society depends upon structure. As the framework disappears within the walls of the house and the skeleton can scarcely be divined beneath the muscles and the skin, so social structures exist beneath the ideas and the agitations of the outer world. They exist, and they obey their proper laws. We would like to attempt, in this study, first of all to make clear the laws which condition all social structure, then to inquire into the economic structure of the enterprise, finally to define, in the light of the results obtained, the meaning and scope of what, to-day, we call Structural Reform.

\section{I}

Construction, bony structure and social structure have three characteristics in common - characteristics attached to the very idea of structure itself:

a-Structure sustains, like a frame, the reality constructed. The house without its framework, the body without its skeleton, society without its institutions would collapse.
b-Structure maintains, rigidly, this reality. Unlike the casing of a house, the expression on the human face or transitory social custom, all of which are subject to change, structure endures.

c-Structure contains a preconceived plan, it materializes the essentials of a motivating idea the plan of the architect, the Idea of the Creator of Life, the political, social or economic ideals of Man.

From these characteristics held in common, we may conclude that social structure will furnish the permanent and organized support, the fixed and determined frame of all social reality. This definition, nevertheless, does not specify that which is peculiar to social structure.

Compared with the biological structure of the skeleton, social structure seems, in effect, to have attributes peculiar to itself. The skeleton realizes a Master Idea but this Master Idea is imposed upon it by God. Hence the perfect adaptation of the skeleton of each species of animal to the conditions of that animal's life. On the contrary, social structure, which also realizes a directing idea, receives that directing idea from Man. Hence the imperfections of adaptation, (more or less serious) hence the continual alterations and hence the periodic upheavals (revolutions) which social structure manifest and undergo. Thus, social structures are differentiated by their imperfections, imperfections resulting from the double condition that man is free and at the same time, that he is fallen. The character of permanence is less accentuated. There is a possibility of reform in structure.

So, our definition becomes more precise: social structure - the permanent support of social reality set up in the light of human freedom.

How can human liberty act upon social structures ? By the setting up of an ideal concept of man and by adhering to that ideal ! So were the structures of ancient Rome erected in accord with the ideal of the «Civic Romanus 》 into which each man projected his tendencies, his passions - the best and the worst. In the same way, an intense fermentation in the literary, philosophical and intellectual worlds preceded the French Revolution. A new ideal of Man was formulated by demanding of human liberty its full adherence of spirit and will. It was in accord with this ideal that the ins- 
titutional structures, born of the Revolution, were set up and codified. Everyone knows how Renan described this «structure », \& A code of law which would seem to have been made for the ideal (in an ironic sense) citizen, born a waif and dying without issue; a code which renders everything transitory, where children are an inconvenience to the father, where all collective and enduring work is forbidden, where the moral unities (which are the true ones) are dissolved with each death, where the provident man is the egoist who plans to have the fewest duties possible, where property is conceived of not as something with moral implications but as the equivalent of gratuitous enjoyment, such a code, I say, can produce only weakness and paltriness. »

There is, in this passage, apart from the judgment of value that it carries, a complete analysis of the function of structure.

On the one hand, this structure, «seems to have been made for the «ideal» citizen 》. It is really an «ideal » conception of man, the structure of which expresses the guiding ideas, determines the conduct and holds firm the diligence and application.

On the other hand, the structure of which Renan speaks, "can only engender...» So, not only does the structure reflect a thought but it produces. It is a mold where men may be formed, informed, deformed or reformed according to whether they submit or rebel. It is a rigid mold to which the social life of each and all must conform.

If human liberty, by its choice and adherence to an ideal, can, by the crises which it provokes, modify structures, these structures, apart from moments of crisis, can determine the conduct of men. Without doubt, each person remains free in his choice and in his acts. Practically, the number of choices possible remains limited. Statistical laws manifest social determinism on the scale of the collectivity in a given structure.

At the end of this brief analysis, we can then define social structure as:-the permanent framework of social reality: a) organised by human liberty in relation to an ideal conception of man: b) determining, by means of positive and negative (to do or not to do) imperatives, the number and the import of personal choices possible in a society so constructed.

II

Modern enterprise is upheld by an economic structure which reproduces, on its own scale, the national continental structure of the neo-liberal capitalism in which it was developed. On the level of the enterprise, ${ }^{1}$ what are then the liberal * ideals, the structure set up by these ideals and, finally, the laws determined by this structure ?

Those economists whom we still call « classicists » considered labour as a commodity. This would not constitute an affirmation of the philosophical order, but simply a misuse of abstraction and logical deduction. Everyone was bewitched in the eighteenth century by the law of supply and demand, only recently discovered, which, to Adam Smith, constituted the Law and the Prophets of political economy. Its real positive value was confused with the normative aspect and they described with complaisance why and how the commodity market would be.brought into a state of harmonious equilibrium by the application of this law. But, the commodity market is the place where the producers and the consumers meet. It is there that the prices are fixed.

Now, the logic of the system demanded an equally automatic and perfect regulation of wages. The temptation was strong and no one resisted it, to apply to the Enterprise (place where Capital and Labour met) the scheme which had so ideally functioned on the commodity market between producers and consumers. \& The welfare of the workers requires that the law of supply and demand function without hindrance." If wages are lowered it is because there are too many demands for positions in the industry; left to themselves the workers would turn to a better paid trade and the salaries would go up in the former, while they would go down in the latter to the point of normal equilibrium. ${ }^{2}$ The effective result of this reasoning was the argument that even for the welfare of the worker, labour should be treated as a commodity. Adam Smith leaves no doubt on this score. « Two quantities of labour, whatever the place,» says he, « are of equal value for him who works. $\$^{3}$ From the economic point of view then, it woud be enough to let labour. conduct itself, or, better still, be treated, as merchandise. It would be enough to establish, in the enterprise, an actual labour -market and the law of supply and demand would extend its regulating influence in all sections of the economic life.

(1) We recall that it is usual to distinguish between a) the level of the enterprise, b) the level of the profession, c) the level of the nation.

(2) Description by J. Lecrenc. Leçons de Droit Naturel, IV, 225.

(3) A. SMrrH. "Inquiry into the Nature and Causes of the Wealth of Nations." 
To correspond with this ideal, enterprise was effectively organised in markets. Neither professional regulation nor State intervention wcre tolerated during the greater part of the nineteenth century, in France or in England. Structure functioned freely. But, it did not function according to the dreams of Adam Smith. In fact, from the beginning, competition required that the employer consider the wages of his workmen as one of the elements of his cost price. His profits grew as the cost price diminished and the selling price increased. Thus wages and profits necessarily varied inversely one with the other. In a structure regulated entirely by the profit motive the entrepreneur, encountering no impediment, is constrained by all the means at his command to avoid the two prongs of the pincers, as, in the reverse sense, the wage-earner-consumer must avoid being caught between low salaries and high prices. Thus what the classicists had omitted to foresee became cruelly apparant: that is; that the merchandise which is purchased at a low price is not thereby altered, while labour which is procured at a low price, not being inert as are commodities, but inseparable from the living man who furnishes it, produces suffering and can let loose $a$ series of reactions directly contrary to the hoped for harmony.

These reactions which followed in the second half of the nineteenth century, lead to the formation of trade-unions which were first of all tolerated, then accepted and regulated by law.

What are the aims of these labour-unions ? To guarantee the security of the worker against the disastrous effects of the mechanical operating of the law of supply and demand. More and more there is a Labour World which has its army - the union; its war material - the strike; its treaty of peace - the collective agreement and its arbitration tribunal - the State. The Union, further, is nicely situated to suggest such laws as those of Minimum Wage and other measures of general interest to the Labour World.

From the realization of the aspirations of the labouring classes is developing the beginning of a real reform in structure. This reform is resulting in an economic situation which has been called the «bilateral monopoly » and à propos of which H. Denis writes, «A regime of bilateral monopoly... although exchanges advantageous to both parties could be realized, produces nothing effective because, actually, the two parties concerned consider nothing of as great importance as their differences. ${ }^{4}$ Is this to say that the strike is

(4) H. Denss, Le Monopole Bilatéral, p. 88. inevitable? Not at all. But experience shows that the strike is relatively frequent and that spontaneous agreement between the two monopolists (Labour and Capital) is relatively rare. Actually, the structure of the bilateral monopoly on the labour market such as results from union action demonstrates a will to understand which is the immense positive acquisition of this regime. But, this understanding is conceived of as the result of $a$ trial of force whether by simple moral persuasion (explaining of motives) or by such acts as the strike or lock-out. So, the wage-earner remains, psychologically, in this structure, the antagonist of the employer.

There are means of obtaining justice by collective regulation but the resort to this means is in the nature of an opposition and not a settlement. Capital and Labour remain opposed on each side of the line where their interests clash. Finally, the wages varying always in inverse ratio to the cost price, the wage-earners are not in any way brought together economically, intellectually or morally in the effort of production. Now, the employers' associations and the labour-unions cannot realize unity on the national level but only at the base of the system - i.e. the enterprise. Employers and workers, ceasing to be through agreement, even collective agreement, buyers and sellers of labour have become companions in mutual work and hope. The reform of the «liberal » structure will not have been attained until it has converted and brought together the opposition remaining within the primary cell of the structure - the enterprise.

\section{III}

The ideal of «liberalism» has produced in enterprise a structure which all too often has given to reality an ugly form and brought about much social suffering. Does there exist an ideal which would better express the personal and social nature of man ? We well know there does - we who have the desire to found a Christian social order which aims at building a world fit for men saved by and in the Man-God. But are we sufficiently aware that the structural reform of enterprise is the key-stone, the framework even of the whole edifice?

Let there be no mistake about it. The program outlined by the Encyclicals aims not only at limiting the havoc of «Liberalism». When Pius XI in «Quadragesimo Anno » recalled the teaching of Leo XIII, it was to bring to mind that « he boldly attacked and overthrew the idols of liberalism »; that he «provoked even amonng Catho- 
lics, suspicion and offense ». And how did Leo XIII overthrow the idols of liberalism ? In the following terms - so full of truth and faith, « Just as the human body is the result of the disposition of the members of the body, so in Society it is ordained by nature that these two classes should exist in harmony and agreement, and should, as it were, fit into one another, so as to maintain the equilibrium of the body politic. Each requires the other; capital cannot do without labour, nor labour without capital. $\gg^{5}$

Is the idea of labour as a commodity resulting from the laissez-faire economy, compatible with this harmonious union in a perfect equilibrium ? «Labour indeed, as has been well said by Our predecessor in his Encyclical, is not a mere chattel, since the human dignity of the workingman must be recognized in it, and consequently it cannot be bought and sold like any piece of merchandise (R.N., 16). Nonetheless, under the prevailing conditions, the supply and demand of labour divides men on the labour market into two classes, as into two camps, and the contention between these parties transforms this labour market into an arena where the two armies are engaged in fierce combat. To this grave disorder which is leading society to ruin a remedy must evidently be applied as speedily as possible. i ${ }^{6}$

The organisation of labour-unions, the negotiation of collective agreements and the arbitration of the State, do these not furnish the remedies ? The whole of the letter of the Sacred Congregation of the Council, of June 5, 1929, to Mgr Lienart, is there to assert and establish this contention. Nevertheless, is this stage final ? It does not seem to be, because, "There cannot be any question of a perfect cure, except this opposition be done away with, and well-organized members of the social body come into being anew, "Orders », namely, in which men are knit together not according to the position they occupy in the labour market, but according to the diverse functions which they exercise in society. ${ }^{7}$ Do the collective agreements concluded by the Unions attain this end ? Not entirely. They are a treaty of peace between two powers. They are not yet the federation of these two powers uniting \& harmoniously in perfect equilibrium. » Actually, there is always the temptation for each of the powerful workers' and employers' groups organized on the national scale, to regulate their economic problems on this same scale.

\footnotetext{
(5) Social Wellsprings. Vol. I, No. 15.

(6) Social Wellsprings. Vol. II, No. 83.

(7) Idem.
}

This was the error of the Italian « carta di labore "; the error of the law of October 4, 1941, in France; the error of certain more recent nationalisations. ${ }^{8}$ There is, besides, the danger of the creation of a collective psychology of claiming and counter-claiming. The «well-organized bodies》, grouping «men, not according to the position they occupy in the labour market, but according to the diverse functions which they exercise in society 》 could not be set up from the very first at the level of the profession or of the nation.

How could they raise up, in the whole body, a structure which could not first of all be realized in each individual cell ? Is it not very evident, on the contrary, that, if harmony between labour and capital were encouraged within all enterprises by the structure itself of the enterprise, these « wellorganized bodies » would result quite naturally in each professional sphere and in the entire nation ? And is it not this structural reform of business which Pope Pius XI envisaged when he counselled to, «Temper somewhat, in so far as possible, the labour contract by elements borrowed from the partnership compact »? At the moment when the contagion of directed economy is alarming the defenders of «free enterprise», do we not find there, moreover, an effective means of rescueing personal initiative from the encroachments of the State in knitting closely all those associated in the conduct of the enterprise ? The greater number of the countries of Europe have seen State Direction - of Socialist inspiration, follow a period of free competition inspired by «liberalism ». This second experience, proceeding from the first, has been more successful. It is from this second setback that the current efforts have been born with the purpose of accomplishing Structural Reform. Surely such an example is worth deep meditation.

Such is then the ideal proposed to us by Christian Social Doctrine. It is not necessary to enlarge upon the fact, which will be further developed, that in «tempering the labour contract by elements borrowed from the partnership compact», the economic antagonism within the enterprise is overstepped. Henceforth, the «share of labour» and the "share of profit» will vary in the same direction. ${ }^{9}$ Labour, then, will no longer be merely a contract, individual or collective, between

(8) See the letter of His Holiness Pius XII to Mr. Charles Flory, President of the Semaines Sociales de France.

(9) "In the natural group or association, wrote Joseph SCHUMPETER about it, the antagonistic elements and the corporative elements combine in a harmonious manner within the limits of a common culture and faith." The partnership compact has for its aim precisely this identification of the co-operating elements. 
a buyer and a seller. Employer and workers will be in some way associated. The Structure thus, will correspond to an ideal of reconciliation, of fusion, and of social unity. There is no doubt that the results will be good. It is not the place of the Province of Quebec to give on the North American continent, public witness of the solid worth of the Social Doctrine of the Church ?
People say:-« But - who ? 》

The Pope answers: «Undoubtedly the first and immediate apostles of the workingmen must themselves be workingmen, while the apostles of the industrial and commercial world should themselves be employers and merchants. ${ }^{10}$

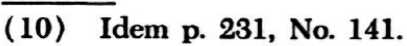

ASSURANCES SOCIALES

\title{
LA COMPENSATION DES ACCIDENTS DU TRAVAIL
}

\author{
Frédéric-T. HECKER
}

Le but de la présente Loi des accidents du travail qui est en vigueur depuis 1931, est de pourvoir à une réparation plus efficace en faveur des ouvriers blessés à leur travail, d'éviter les litiges et d'assurer le service prompt et exact des presta. tions à l'ouvrier et ses dépendants sans obérer indûment l'employeur.

La Loi offre égale protection à l'ouvrier pour tous les accidents survenus par le fait ou à l'occasion de son travail au lieu de s'appliquer seulement à ceux qui sont dus à la négligence du patron; elle attribue le règlement des réclamations à la Commission des Accidents du Travail aux lieu et place des tribunaux; et dans la plupart des industries auxquelles la Loi s'applique, elle rend la responsabilité patronale collective au lieu d'individuelle.

\section{Application de la Loi}

La Loi ne s'applique pas à toutes les industries, mais seulement à celles énumérées dans les Cédules 1 et 2.

La Commission perçoit des cotisations des employeurs dirigeant les entreprises énumérées dans la Cédule 1; et ces cotisations, sous un système de responsabilité collective, constituent le fonds d'accident à même lequel sont payées les compensations et l'assistance médicale. Dans le cadre beaucoup plus restreint des industries énumérées dans la Cédule 2, chaque employeur est tenu personnellement de payer la compensation et de pourvoir à l'assistance médicale en faveur de ses ouvriers blessés par suite des accidents.

Des actions peuvent encore être intentées devant les tribunaux à l'encontre d'employeurs dont les industries ne sont pas assujetties à la Loi en établissant la négligence ou l'incurie de ces derniers, et la présente Loi n'enlève aucun des recours de droit commun appartenant aux personnes qui ne sont pas assujetties à ses dispositions.

\section{Quand la compensation est payable}

La compensation est payable en réparation de toute blessure corporelle résultant d'un accident survenu par le fait ou à l'occasion du travail, et dans les cas de certaines maladies énumérées dans la Cédule 3 de la Loi.

Les seules exceptions à la règle générale sont:

(1) Lorsque l'incapacité résultant de l'accident dure moins de sept jours;

(2) Lorsque l'accident est uniquement imputable à l'imprudence grossière et volontaire de l'ouvrier et qu'il n'entraîne ni la mort ni l'incapacité grave de la victime.

Le fait de la négligence ou de labsence de négligence de l'employeur ou de l'ouvrier ne change pas la situation, et les moyens de défense basés sur la loi civile ordinaire ne s'appliquent pas. 